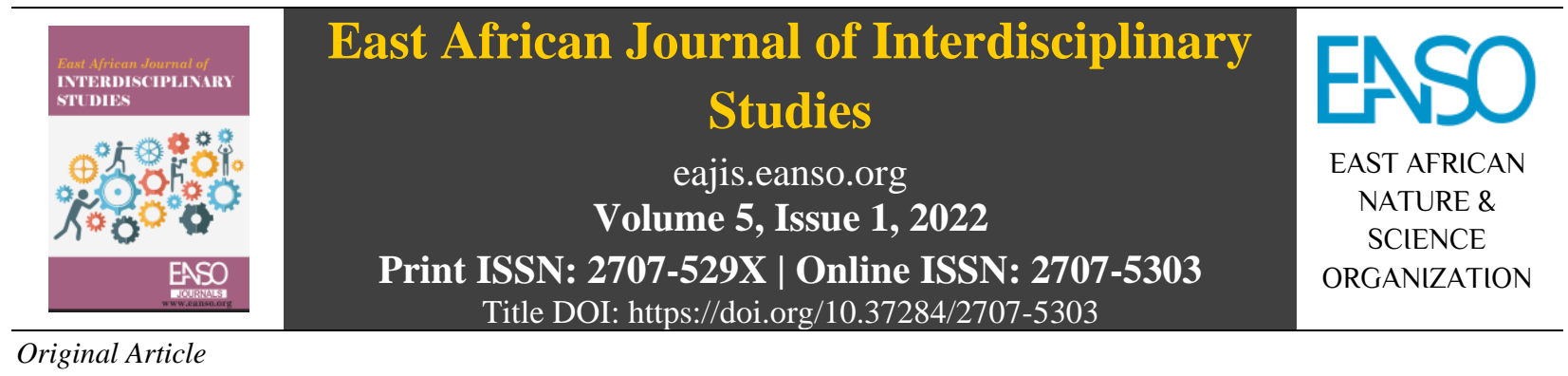

\title{
Physical Resource Management and Maintenance Culture in Nigerian Universities.
}

\section{Stella Ofor-Douglas, $P h D^{1}$}

${ }^{1}$ University of Port Harcourt, Rivers State, Nigeria.

* ORCID: https://orcid.org/0000-0002-6855-2106; Author for Correspondence Email: stellaofor031@ gmail.com

Article DOI: https://doi.org/10.37284/eajis.5.1.566

\section{Date Published: ABSTRACT}

01 March 2022 This paper deals with physical resource management and maintenance culture in Nigerian universities. Physical resource is the resource that can be seen

Keywords: (tangible). Resource management is the proper utilization and management of resources such that they are adequate and efficient for the needs of individuals

Education, in an organization. The importance of resource management in universities is to

Physical Resource, see whether the human resource is over or under-allocated in a particular faculty in the university to avoid wastage. Maintenance culture refers to the measures

Resource taken so that materials and resources are maintained properly. Universities refer Management, to institutions of higher learning whereby an individual seeks to further his Maintenance education after the secondary school level. The absence/ poor maintenance of Culture. physical resources in Nigerian universities would undoubtedly lead to a decline in the productivity of the university. This paper is to provide a means of efficient management and maintenance of physical resource in Nigerian universities. The objective of this paper is to proffer solutions to the challenges of effective management and maintenance of physical resources in Nigerian universities. The challenges facing the effective management and maintenance of physical resources in Nigerian universities were provided in this paper to include inadequate funding, inadequate facilities, and misuse of university facilities, amongst others. A conclusion was made and a way forward for the challenges facing the efficient management and maintenance of physical resource in Nigerian universities were provided. This includes the provision of adequate funds, punishment of greedy administrators that covert funds, provision of adequate modern facilities, proper maintenance of physical resource from time to time, amongst others.

\section{APA CITATION}

Ofor-Douglas, S. (2022). Physical Resource Management and Maintenance Culture in Nigerian Universities East African Journal of Interdisciplinary Studies, 5(1), 40-49. https://doi.org/10.37284/eajis.5.1.566.

\section{CHICAGO CITATION}

Ofor-Douglas, Stella. 2022. "Physical Resource Management and Maintenance Culture in Nigerian Universities". East African Journal of Interdisciplinary Studies 5 (1), 40-49. https://doi.org/10.37284/eajis.5.1.566.

40 This work is licensed under a Creative Commons Attribution 4.0 International License. 
East African Journal of Interdisciplinary Studies, Volume 5, Issue 1, 2022

Article DOI: https://doi.org/10.37284/eajis.5.1.566

HARVARD CITATION

Ofor-Douglas, S. (2022) "Physical Resource Management and Maintenance Culture in Nigerian Universities", East African Journal of Interdisciplinary Studies, 5(1), pp. 40-49. doi: 10.37284/eajis.5.1.566.

\section{IEEE CITATION}

S. Ofor-Douglas. "Physical Resource Management and Maintenance Culture in Nigerian Universities", EAJIS, vol. 5, no. 1, pp. 40-49, Mar. 2022.

\section{MLA CITATION}

Ofor-Douglas, Stella. "Physical Resource Management and Maintenance Culture in Nigerian Universities". East African Journal of Interdisciplinary Studies, Vol. 5, no. 1, Mar. 2022, pp. 40-49, doi:10.37284/eajis.5.1.566.

\section{INTRODUCTION}

An organization requires resources to carry out its goals and objectives. A resource may be financial, human, time, or physical resources. The focus of this paper is that of physical resource, and it includes all the facilities and structures that one can physically see in a university. In any educational setting, resources are important for the day-to-day running of the school. Without resources, the organization cannot function or be productive. Physical resource in essence includes buildings and structures, ICT facilities, laboratories, and equipment. There is no possible way that a school can be effective without physical resources. Unfortunately, physical resource is in short supply or are unavailable. Therefore, the author has chosen to discuss the importance of physical resource management and maintenance culture in Nigerian universities in the hope that it would inspire readers to properly use, maintain and manage the physical resource in their universities so as to ensure productivity and achievement of their university goals and objectives.

\section{Physical Resource}

Abdul Kareem (2011) in his own view concluded that resources are assets required to achieve set academic goals and appropriate school-level teaching and learning practices. Thus, it is deduced that resources are vital to obtaining standard education and provide effectiveness in the teaching and learning schemes. Teaching and studying do not take place in a void area but instead in physical surroundings which call for using sources. Educational sources include human and non-human (material, physical and economic resources). Physical resources in education are sources that include all systems and canters which can be the classrooms, labs, gadgets, and facilities in the college surroundings. This means physical resources are important for educational goals. Uchendu, Ekanem, and Jonah (2013) see physical resource as the physical properties that can be moved and fixed - assets belonging or allocated to an educational institution to improve teaching. As such, physical resource are the visible structures which are either mobile or immobile and are allotted to an institution of learning to enhance the teaching process. Usman (2016), view physical resource to include machines, raw materials, automobiles, and various items than can facilitate an organization's activities and processes. Therefore, physical resource is composed of machinery, raw materials, transportation, and other mechanical operations. He states that inside the educational system, the physical resource includes the classrooms/lecture rooms, personnel workplaces, laboratories, libraries, vehicles, health centres, fitness centres, which directly or indirectly play a role in the attainment of educational goals and objectives. Wolu (2019) maintained that physical resource serves as tools in the school system to fulfil and achieve educational goals and objectives. This implies that physical resource acts as a support system in educational institutions to actualize their learning goals. Enaohwo in Wolu (2019) affirmed that physical resource are essentially devices used to carry out activities and operations of the school therefore, we cannot disregard them in the context of financial rationalization of educational development planning. This means that physical resource is an essential instrument used to carry out operations in schools and as such, they cannot be overlooked when it comes to the economic context of developing education. Physical resource as considered through Ile (2019) includes academic facilities (classrooms, seats, laboratories, libraries, , chalk, books, marker forums, audio-visual materials, gardens and typing swimming pools, and so on), leisure centres (fields, balls, gymnasiums, 
lawns, swimming pool device, tennis, enjoyment parks and all sports, games, etc.), residential facilities (hostels, staff quarters, and many others), and general-purpose facilities (space facilities which can be advanced and underdeveloped areas that can be transformed to different uses beyond their authentic use, biotic and abiotic environment).They refer to the site, building, furniture, and equipment that contribute to the development of a positive learning environment and quality education for all students (Ayeni and Adelabu, 2012). Obanya (2009) sees physical resource to include those teaching materials such as books, charts, and computers which are supposed to make learning and teaching achievable. This implies that physical resource comprises of those teaching apparatuses which include books, charts and computers that make teaching and learning attainable. A healthy physical environment is one in which students feel safe, cared for, and relaxed, with the support of adequate and relevant physical resource. The school heightens their productivity in the teaching and learning process (Asiabaka, 2008) cited in Onwuliri and Amie-Ogan (2020); Obanya (2009) Bringing back teachers to the Africa school. International Institute for Capacity Building in Africa. UNESCO.) The learning environment thus increases fecundity in the educational operation.

This paper aims to provide means of the efficient management and maintenance of the physical resource in Nigerian universities. The objective of this paper is to proffer solutions to the challenges of effective management and maintenance of physical resource in Nigerian. This paper is thus meant to proffer solutions to the challenges of effective management and maintenance of physical resource in Nigeria.

\section{Importance of Physical Resource}

- Students are better equipped with appropriate knowledge and skills.

- Physical resource gives a conducive environment for learning.

- It makes teaching and learning friendly.

\section{Significance of Physical Resource}

- It gives a better learning experience
- Quality and standard of education is high with the availability of physical resources.

- Research is encouraged amongst lecturers with the presence of physical resources, while knowledge and skills will be enhanced.

Agabi (2010) opined that lack of resources has long been a dominant aspect of chronic educational deprivation. This implies that resource inadequacy has been a notable facet of habitual education deficiencies. He further reiterated that the resources which are diminishing are also outnumbered by the individuals using them. This suggests that resources are deprecating and are also insufficient for the persons utilizing them. Again, Agabi (2012) posited that the resources provided by the government for the implementation of education projects in Nigeria are insufficient and irregular due to the frequency of industrial action in the education sector. This implies that resources supplied by the Nigerian government for the facilitation of education schemes are wanting as accentuated by the recurring industrial actions in the education sector. It is important that physical resources are made available for optimum results. Adetoro (2008) opined that the overwhelming rise in the demand for university education in Nigeria, has negatively impacted on the existing limited resources. Based on the above, it is seen that the increased demand for university education in Nigeria has largely influenced the existing constructed resources. He further stated that the available physical resource does not match the population of both staff and students. In our universities today, students and lecturers suffer obstacles due to insufficient physical resource. It has come to the attention of everyone that although these facilities are not properly maintained, one of the major challenges to growth and development in Nigeria educational system is the perennial shortfall in the provision of essential resources, either in form of inadequate or unqualified staff or sheer lack of physical resource to service the system.

\section{Resource Management}

A resource is something that helps an organization achieve its goals and objectives in order to boost production. The importance of resource management in universities is to determine whether human resources are excess or under-allocated in a 
specific faculty to avoid waste. The essence of university education is for teaching, research, dissemination of knowledge and serves as a knowledge bank and provides community service. For this to be achieved in the university system, quality education and facilities need to be put in place. It is necessary to provide quality physical resources, conducive teaching and learning environment, and constant maintenance culture to achieve the goals and objectives of the university both at the federal and state level.

\section{Identification of Physical Educational Resources}

Physical resources that can be found in the educational sector include the following:

- Classrooms

- Hostel Buildings

- Laboratory facilities

- Library and ICT facilities

- Special rooms

- Desks, benches, and instructional aids

\section{Significance of Physical Resources}

- It gives a better learning experience

- Quality and standard of education is high with the availability of physical resources.

- Research is encouraged amongst lecturers with the presence of physical resource, knowledge, and skills are enhanced.

\section{Maintenance Culture}

- Maintenance culture is routine that is performed to keep equipment, machinery in a good working condition or better yet to keep this machinery, equipment in service. Ajayi (2007) upheld that physical resource renovation are all of the activities embarked upon to support the preliminary use-value of the plant, which entails sweeping of the flooring and environment, dusting, mopping, scrubbing, and washing of school plant, mowing of the lawns and playgrounds, restoration of facilities, pest control, fire prevention and safety. Igbeneidion (2014) posits that preventive maintenance in its best form is spending little money now to do regular inspections and renovations for you to minimize future big-ticket prices and extend the useful life of buildings and equipment. In effect, preventive maintenance in its plainest form is to disburse minimal amounts presently to carry out routine inspections and preservation to curb large expenses in the future and to lengthen the operational span of structures and equipment. Okotoni (2013) emphasized that failure to commission and conserve available resources would eventually render them inoperable, ineffective, and useless. This statement stresses that the absence of essential and recurring maintenance of existing resources would eventually lead to those resources being ineffective and impractical. Consequently, it is crucial to maintain the quality of available resources to avoid waste and achieve effective use that would increase productivity. Asabiaka (2008) cited in Dangara (2016) mentioned that the following type of maintenance ought to be followed inside the facility maintenance plan. These are preventive, routine, emergency repairs, and predictive maintenance.

- Preventive maintenance: This is a type of maintenance carried out on university facilities to avoid breakdown and ensure the optional performance of the facility. Up to date information about the facility is required to serve as a guide for the maintenance team. Preventive maintenance saves cost and time, it is usually an integral part of the management practice in societies where maintenance culture is well established. Decisions on preventive maintenance are collectively made and implemented.

- Routine maintenance: This is carried out periodically as scheduled by the university managers. Depending on the agreed-upon schedule, facilities may be serviced monthly, quarterly, or even annually. Manufacturer's guide and provide information on the native and maintenance intervals. To avoid equipment failure, university administrators follow these guidelines. 
- Emergency repairs: This is very common in the management of university facilities where maintenance culture is not well established. It takes place when a facility breaks down and urgent measures or steps had to be taken to remedy the situation. In this regard, collective decision-making may not be possible because there may be limited time to bring together all necessary individuals to make decisions. It is also expensive because due to lack of maintenance, the extent of the damage may demand total replacement of the facility or a high cost of repair.

- Predictive maintenance: This involves the use of computer software to predict equipment failure.

\section{EDUCATION}

Education is the process of facilitating learning, or the acquisition of knowledge, skills, values, beliefs, and habits. Effective education is a learning experience that creates an inherent and lasting change in a person's thinking and ability to do things (Adeyemi, 2014). This means that effective education is a learning experience that results in a lasting change in a person's rationale and ability to do things. Education is crucial in the development of any economy and nation, a contemporary and flourishing educational system constitutes a wide range of activities that would facilitate an effective and quantitative education of eminent standard at primary, secondary, and tertiary levels of education (Davidson, 2012). He, therefore, posits that education is vital in the expansion of any economy and nation, a modern and prosperous educational system comprises of a vast series of activities that support a productive and measurable education of notable standard at the primary, secondary, and tertiary levels of schooling. Adegbesan (2011) view education as a contributor to individual development, by increasing their productivity and income at work, and allowing for participation in economic and social life. In other words education leads to individual development, improves innovation and income at work and allows for involvement in economic and social strata. Shofolabo in Uyanga and Emana (2016) rightly see education as bringing out the innate power and potential of individuals in the society and the acquisition of skills, aptitudes, and competence necessary for self-reliance and for dealing with life's problems. It is thus deduced that education is the foremost and inherent ability and capability of individuals in the society and the attainment of skills, inclinations instincts needed for independence and resolving life challenges. Tabotnip (2010) rightly described education as the process of gaining knowledge that begins from birth to death. In other words, education is seen as the means of acquiring knowledge that is initiated from birth to death. Eunice and Zita (2013) rightly described education as having two ideas inherent in the world. This means education is seen as possessing two ideas that are essential in the world. One is that leading out into new knowledge and experience while the other is that of feeding and thereby growing and developing. Akani (2012) observed that education is an instrument of positive change which empowers its recipient to be creative and become change agents useful to themselves and the society at large. This implies that education is a device of positive change that enables one who receives it to be innovative and become an instrument of change which are valuable to themselves and the society as a whole. Mu'uazu (2011) pointed out that quality education connotes not only the production of college or university graduates who can perform efficiently and effectively but those who can function with the right types of values and attitudes for the survival of individuals and society in general. It is seen that quality education refers not only to the provision of college or university graduates who can function effectively but those who can showcase the required values and demeanor essential for the viability of individuals and society as a whole. Omemu (2015) citing Anikweze (1989) established that quality education as an inventory of highly valued knowledge is also reflected in the observable behaviour and performance of a product of the education system. This statement implies that quality education as a system of highly rated knowledge is also viewed as noticeable behaviour and it is an execution of the outcome of educational system. Oseni (2014) adds that it is the extent to which education accomplishes the various roles ascribed to it such as the usefulness of education for employment relevant to the developmental needs of the recipients and the society in which the individuals live and operate as citizens, and 
achievement of students. This means that it is the degree to which education achieves the numerous functions allotted to it such as the necessity of education for employment needed for the developmental requirements of the recipients and the society where these individuals reside and question as citizens and achievement of students. Onye and Ajuzie (2018) maintained that education is that value which the older generation gives the young ones that enable them to develop attitude, abilities, skills and other behaviour which are of positive impacts to the society where they find themselves. This implies that education is that value which the older generation bestows on the youth to empower them to forge skills, demeanours, and capabilities that brings abrupt and positive effects on the society where they reside. Mbachu (2013) opined that education must be an effective tool and of good quality to enable the recipient to grow into a functional member of their family and the country. This is to say education needs to be strong and of favourable quality to ensure the recipient develops into a productive member of his/her family or country. Selvamm and Devi (2014) also posited that education is the gradual process of acquiring knowledge, that education is a preparation for life, explaining that the development of any nation depends mainly on the standards of its educational institutions, that education is the most powerful and effective tool to bring about radical behavioural change in students. Going by this, education is the gradual strategy of obtaining knowledge, and cultivation for life in the sense that the development of any nation is based on the principle of learning institutions. Also, that education is the most potent and effective device for prompting revolutionary improvement in the conduct of students.

\section{Concept of University Education}

University education is attained after the secondary school level. It is the production of qualified and trained manpower into the society. The essence of university education is for teaching, research, dissemination of knowledge and knowledge bank, and community services. For this to be achieved in the university system, quality education and facilities need to be put in place to achieve that. That is why it is necessary to provide quality physical resource, a conducive teaching, and learning environment, and constant maintenance culture to achieve its goals and objectives without compromise for sustainability in Nigerian universities both at the federal and state level. University education as we see it today is a complex system facilitating teaching, research, and international co-operation (Mishra, 2017). This implies that university education as we have it today is a complex network promoting teaching, research, and international collaboration. Also, Tanangahar and Orokpo (2018), view quality university education to involve the coordination of finance, infrastructural facilities, staff, students, and education policies. In any educational setting, resources are important for the day -to- day running of the school. Physical resources are therefore resources that include buildings and structures, ICT facilities, laboratories, and equipment. There is no possible way that a university can be effective without the physical resources. Unfortunately, physical resources are depleting in short supply or are unavailable.

\section{Importance of University Education}

University education is more than the next level in the learning process; it is a critical component of human development worldwide. It provides not only the high-level skills necessary for every labour market but also the training essential for teachers, doctors, nurses, civil servants, engineers, humanists, entrepreneurs, scientists, social scientists, and a myriad of other personnel. It is these trained individuals who develop the capacity and analytical skills that drive local economies, support civil society, teach children, lead effective government, and make important which affect entire societies also Ofor-Douglas (2020) highlighted the benefits of university education as follows:

- University education will help an individual to succeed in today's workforce and establish an enjoyable career of his/her choice.

- The job market is extremely competitive, and employers require the services of skilled employees to work for them. This skill can be developed in the university.

- Individuals are required to have degrees for a wide range of careers such as medicine, 
education, engineering, accounting, and law, and the university provides for the obtainment Of Such Degrees.

\section{Problems of Physical Resource Management in Nigerian Universities}

Agabi (2010) correctly said that the limited physical resources available are not only over-utilized, but also neglected. This implies that the scare physical resource available are not only over exploited but are also poorly preserved. The libraries (both traditional and electronic) are ill-equipped and insufficient in terms of space and number. This means that libraries conventional and electronic libraries are meagrely furnished and usually scare in the area of capacity and number. (The National Scholar, 2013), and (The National Scholar, 2013) (Agbo, 2013). According to Uchendu, Ekanem, and Jonah (2013), the current global economic recession, as well as the lack of resources has necessitated the widespread preaching of the gospel of conservation culture at all levels of the Nigerian educational system. This implies that the present economic slump being encountered by the world over and the consequent demise of resource availability has made it needful that the message of maintenance culture be shared expensively at all levels of Nigeria's education system. A variety of variables have been identified as posing challenges to resource availability and upkeep in universities, according to studies (Ukeje, Akabuogu and NDU, 1992; Adetoro, 2008; and Uchendu, Ekanem, and Jonah, 2013). They concisely describe the elements that contribute to the poor maintenance of physical resources in universities in Nigeria include the following:

- Poor governance and management on the part of government toward quality education for her citizen

- Corruption: Funds meant for education infrastructure, salary payments, maintenance, and running of universities and institutions are being diverted and mismanaged.

- Poor funding and neglect of educational physical facilities/resource

- Poor university infrastructure and facilities
- Political instability on the part of the government on policies implementation

- Poor teachers' welfare as well as irregular payments of salaries

- Lack of dedicated university administrators

- Poor inspection and supervision of the university

- Lack/inadequate learning and teaching facilities in the university

- Unhealthy learning environment

- Overutilization of available physical facilities

- Poor working conditions for lecturers

- Lack of technological know-how on the part of the university administrator

- Shortage of manpower in the university

- Negligence of university administrators.

\section{Challenges of Physical Resources and Maintenance Culture in Nigerian Universities}

Certain challenges that are faced where physical resources maintenance are concerned. NOUN (2009) indicated the following as challenges of physical resources:

- Inadequate Facility/Poor Infrastructure: This serves as one of the principal issues dealing with the effective management and maintenance of physical resource in Nigerian universities. Fafunwa (2010) asserted that there is a gap in the quality of university students, in crowded classrooms, the usage of insufficient and obsolete equipment, disillusioned lecturers, etc. This implies that there is a rift in the quality of students in stuffed classrooms who make use of insufficient and faulty equipment, aggrieved teachers etc. Bulama and Tijani in Adeniran (2013) pointed out that a situation where classes are held under trees poses a risk to significant school activity and quality education at all levels. This means that a condition where classes are carried out under trees creates a threat to purposeful academic activities and quality education at all levels. University facilities are 
the material sources that facilitate effective teaching and learning in universities. The state of infrastructural delay in many universities in Nigeria is a manifestation of negative investment in the system. Ahmed (2003) referred to in Dangara (2016) found out that in most of the nation's universities, teaching and learning takes place beneath maximum unconducive surroundings, lacking the basic materials and thus hindering the fulfilment of educational objectives. This implies that in a majority of the nation's schools, teaching and learning occur in very unconducive areas with inadequacy of basic teaching and learning materials which serves as a barrier to achieving educational objectives.

- Lack of Funding: In Nigerian institutions, physical resources must be carefully managed and maintained. This would be done only if sufficient funding were available. Funding is the heartbeat of education and for education and for educational programmes to have meaning, all that is required in terms of the fund must be in place for the provision of human and material resources (Ise, 2014). This implies that funding is the core of education and for education and educational programmes to have values, what is needed is funding to be in place to promote the availability of human and material resources. Oladipo and Adebakin (2015) submitted that poor funding explains infrastructural deficiencies and poor performance by teachers and students. It is deduced from the statement above that inadequate funding surmises infrastructural materials and poorly quality performance of teachers and students. Lucky, Uwaezuoke and Seibai (2018) upheld that "it is a known fact that in almost all the economy, education receives the least fund in budgetary allocation". Amadi (2013), noted that there is a drastic decline in education capital expenditure, and budgetary allocations have been less than $14 \%$. This means that there is an immense decline in the capital expenditure for education, and as the trend progresses; budgetary allocations are as little as below $14 \%$. Nwachukwu (2014) traced the challenges of funding education to policy and strategy instability, inconsistency, inefficient management, wastage, and leakages which have overriding macro-economic conditions that determine the fate of the sector. Also, Adeniran (2013) observed that the low level of Nigerian development today is the result of the poor performance of her education system. This implies that the poor level of Nigeria's development presently is caused by the meagre rate of performance in the education sector. Ikpeze (2010) revealed that the challenges confronting tertiary institutions in Nigeria include financing issues, political interference, the growth of private tertiary institutions, management challenges, and so on but further admitted that the challenge dealing the ultimate deathblow is that of underfunding of tertiary institutions. It was thus made known that the issues plaguing tertiary institutions in Nigeria consist of poor finance, political interference, the increase in private tertiary institutions management issues and etcetera but subsequently admitted that the issues dealing the heaviest blow on tertiary institutions is underfunding. Adeyemi (2011), on his part of his study on the financing of education in Nigeria: an analytical review, identified the inadequacies in educational funding in the country and recommended that since the educational system needs to be financed, the private and public sector's financing should be encouraged. The above author in his study on financing education in Nigeria contributed to the field of knowledge in an analytical review which revealed the setback in the nation and proposed that since the educational system requires financing the private and public sectors financing needs to be improved upon drastically.

- Poor management: Some administrators of institutions are not left out from mismanagement and corrupt attitude as regards funds allocated to their institution. The tendency and the urge to become wealthy often lead to such practices. Pilfering of university facilities, are all managerial problems associated with the availability and utilization of resources. In Adenugba (2013) opinion the internally generated revenue to boost the finance of the institution, is hampered by corrupt practices being perpetrated by those that are involved in collecting and keeping records. At such revenues generated are not properly accounted for. It was thus observed from the above statement that 
internally generated revenue that is relied on to hasten financing is plagued by corruption on the part of revenue officials. Those responsible for keeping records of revenue so generated are not giving reliable financial statements.

\section{- Supply of substandard educational resources:} Corruption in the system has in certain cases aided the provision of poor school resources (which rarely endure the test of time). Because they are readily broken, these resources are frequently ineffective in aiding the educational process.

- Misuse of university facilities: University workers may misuse the university's physical and material resources, either intentionally or inadvertently, or owing to a lack of technical knowledge. There may also be a lack of maintenance and overuse of university facilities.

\section{CONCLUSION}

This paper discussed physical resource management and maintenance culture in Nigerian universities. In order for Nigerian universities to achieve their set goals and objectives, it is important for the physical resource within the universities to be properly managed and maintained. Physical resources were discussed to mean the physical structure and materials in the university through which the university uses to achieve its set goals. Where these resources are not maintained properly, there will be no chance of productivity occurring in the university. The paper discussed some problems universities face when trying to manage and maintain physical resources effectively. They include lack/inadequate funding, misuse of available facilities, supply of substandard facilities, amongst others. Despite the fact that there are numerous problems facing the effective management and maintenance of physical resource in Nigerian universities, university administrators can adopt the following suggestions;

\section{WAY FORWARD}

- Facilities should be serviced regularly to detect faults thus ensuring physical resource maintenance.
- Facilities which are up to standard and are modern and new should be obtained.

- Various personnel should undergo training in the operation of these facilities, specifically the ICT and laboratory facilities.

- University administrators in Nigeria should take precautionary measures and maintenance culture as a top priority in their universities both federal and state universities, in order to sustain the physical facilities in their various universities.

- Adequate funds for the maintenance of physical resource in universities should be provided by the Nigerian government through the Federal Ministry of Education, organizations like TET Fund, NGOs, and other financial aid institutions.

- Adequate power supply should be provided to Nigerian universities so as to enable proper maintenance of ICT facilities.

- Routine supervision should be imposed in Nigerian universities to ensure proper maintenance of these physical resource and also to ensure that they are made available when funds have been disbursed for the provision of these physical resource.

\section{REFERENCES}

Abdulkareem, A. Y., \& Oyeniran, S. (2011). Managing the performance of Nigerian universities for sustainable development using data envelopment analysis. International journal of academic research in business and social sciences, $1,1$.

Adegbesan, S. O. (2011). Establishing quality assurance in Nigerian education system: Implication for educational managers. Educational research and Reviews, 6(2), 147-151.

Adeniran, F.I. (2013). Language Education: A Tool for National Development Contemporary Issues in Teacher Education for Value Orientation in Nigeria. Glory-land Publishing company, Mokola Ibadan. 
Adenugba, A.A. (2013). The effort of internal revenue generation infrastructural development: A study of Lagos State internal revenue service. Journal of Education and Social Research. (392), 419-436.

Adeyemi, C.M. (2011). Achieving Improved Teachers Capacities in Nigeria: Impact of Policy Reforms and Social Dialogue Abuja: UNESCO Nigeria Office.

Adeyemi, J.K., and Inegbedion, J.O. (2014). The economics of scale of distance education in Nigeria, Journal of Education Studies and Management 1(2), 63-75.

Adieme, F.G., \& Sergeant-Awuse, V.D. (2016). Benchmarking for productivity in schools. In S.O. Oluwuo \& J.D. Asodike (Eds). Managing schools for productivity emerging perspectives. Port Harcourt: Pearl Publishers International.

Adetoro, J.A (2008). Resource Management in Education. J.B. Babalola and A.O. Ayemi (Eds) Educational Management: Theories and Task. Lagos: Macmillian Nigerian Publishers Limited.

Agabi, C. O. (2012). Education as an economic investment. International Journal of Scientific Research in Education, 5(1), 1-11.

Agabi, C. O. (2010). Prudential approach to resource management in Nigerian education: A theoretical perspective. International Journal of Scientific Research in Education (IJRE) 13(12) p. 94-106.

Agbo, E.B. (2013). Poor accommodation stalls student progress. The national Scholar. Public universities: clouds in search of silver linings. $A$ publication of the Academic Union of Universities (ASUU). Pg. 35-36.

Ajayi, I.A. (2007). Issues in school management. Lagos: Bolabay Publishers.

Akani, C. (2012). The effect of globalization on Nigerian education. Global Advanced Research Journal for Social Science. 1(5). 92-100.

Amadi, N.M. (2013). Financing of Education in the $21^{\text {st }}$ century, options and challenges. Journal of collaborative research and development (JCR 56).

Ayeni, A.J. \& Adelabu, M.A. (2012). Improving learning infrastructure and environment for sustainable quality assurance practice in secondary schools in Ondo State, South-West, Nigeria. International Journal of Research Studies in Education, 1(1), 61-68.

Dangara, U.Y. (2016). Educational Resources: An integral Component for Effective School Administration in Nigeria. Research on Humanities and Social Sciences. Vol. 6, No. 13, 2016.

Davidson, A. (2012). Current Educational Issues in Computer Science Education: Problems and Prospects. The Multidisciplinary Journal of Research Development. 20(2), 155-162.

Ebong, J.M. (2013). School Finance Management in J.D. Asodike, J, M, Ebong, S.O. Oluwuo \& Abraham, N.M. (eds). Contemporary Administrative Teaching Issues in Nigerian Schools. Owerri: Alphabet Nigerian Publishers.

Eunice, C.U., \& Zita, C.O. (2013). A catalogue of existing reforms and innovation in Nigeria Education. Kano: West and Solomon Publishing Co. Ltd.

Fafunwa, A. B. (2010). Fafunwa's last interview: Remember me as somebody who promoted use of mother tongue in schools. The Punch, 3 .

***French, W.L. (2011). Human Resource Management Honghton Mifflin Company, Boston.

***Igbeneidion, D. A. (2014). Facilities management in school. In F.N. Obasi \& J.D. Asodike (Eds). Educational resource management. Port Harcourt: Pearl Publishers.

Ikpeze, N. (2010). New Industrial Policies and Perspectives for manufacturing in Nigeria in Itans, H. bass et al. African Development Perspective year book Vol. 11 itamburg: Lit Verlag.

49 This work is licensed under a Creative Commons Attribution 4.0 International License. 
H. bass et al (eds), African Development Perspective year book. Vol (11) itamburg: LitVerlag.

Ile, K.C.G. (2019). Effects of lack of plant maintenance on administrative duties. In N.P. Ololube (Ed). Encyclopedia of Institutional Leadership, Policy and Management: A Handbook of Research in Honour of Professor Ozo-Mekuri Ndimele Volume III. Port Harcourt: Pearl Publishers.

Ise, F.I. (2014). Funding: A veritable Tool in University Administration: Contemporary Issues in the Management of Tertiary Institutions in Nigeria, Vol. 1.

Lucky, N.C., Uwaezuoke, M.I. \& Seibai, L. (2018). Education Law and Students Personnel Governance at the Secondary Education Level in Aba South LGA of Abia State. African Journal of Educational Research and Development (AJERD). 10(2)251-262 NAEAP Publications.

Maduewesi, E.J. (2010) Nursery Education in Universal Basic Education. (U.B.E) Scheme. The Nigerian Universal Basic Education, Journal Vol. No 2. P8-15.

Mbachu, C.E., (2013). Higher education a key to human capacity development. African Journal of Higher Education Studies and Development. Development. International of theory, policy and Practice for sustainable development. Port Harcourt, CHESS Uniport.

Mishra, S. (2017). Quality assurance in higher education. An introduction Bangalore India: NAAC and Col.

Mu'uazu, B. (2011). Examination malpractice and the quality of education in Nigeria. The Journal of Kumbotso Teacher Education, 2(2), 123-126.

National Open University of Nigeria (NOUN, 2009). Principles of institutional administration: Lagos Gold's prints limited.

Nwachukwu, P.O. (2014). Funding education for sustainable development in Nigeria; Challenges, and the way forward: Journal of Education and Practice. 5-20. 2014.
Obanya (2009) Bringing back teacher to the Africa school. International Institute for capacity Building in Africa. UNESCO.

Ofor-Douglas, S. (2020). Quality Assurance in Managing University Education in Nigeria. International Journal of Educational Management (IJEM), 18 (2), 185-202.

Okotoni, C.A. (2013). Physical resources maintenance in public secondary schools in South-Western Nigeria: Leadership quandary in effective management. Ile-Ife, Nigeria: Obafemi Awolowo University.

Oladipo, S.A., \& Adebakin, A.B. (2015). Funding culture as quality higher education in Nigeria: Implications for policy improvement. Journal of studies in education, 14(2), 149-158.

Omemu, F. (2015). Causes of examination malpractice in Nigeria schools British Journal of Education, 3(7), 34-41.

Onwuliri, I.N., \& Amie-Ogan O.T. (2020). Physical Resource Maintenance for Sustainability of Secondary School Education in Rivers State, Nigeria. International Journal of Progressive and Alternative Education, 6 (1) 372-382, January, 2020. ISSN: 2408-6452.

Onye, C. O., \& Ajuzie, N.E. (2018). Fundamentals of teaching/Learning Accounts and Economics in a digital age. Owerri: Cape Publishers Ltd

Oseni, A. I. (2014). Effect of examination malpractice on Nigeria graduate productivity in the

labour market crew. Journal of Educational Policy and Entrepreneurial Research (JEPER), 1(2), 80-85.

Selvamm, S.K.P., \& Devi, R. (2014). Components of ICT in teacher education. Education and social structure, New Delhi: Randon Publications Special Libraries Association, 2003. (50).

Tangahar, B.A., \& Orokpo, A. (2018). Influence of funding on the provision of quality science education in Nigeria universities. Issues of Quality Education in Nigeria. Book of Reading,

50 This work is licensed under a Creative Commons Attribution 4.0 International License. 
Department of Curriculum and Teaching, Benue State University, Makurdi.

Tabotnip, J.E. (2010). Educational Planning. Onisha: West and Solomon Publishers Company Ltd.

The National Scholar (2013). The Needs assessment of Nigerian universities report. In public universities Clouds in search of (silver linings. A publication of the Academic Staff Union of Universities (ASUU). 9(2). P. 42-49.

Uchendu, C.O., Ekanem, U.C.C. \& Jonah, S.T. (2013). Resource Maintenance for the provision

of educational services in public and private secondary schools in Rivers State, Nigerian European Journal of Business and Social Sciences 2(1). P. 15-23. Retrieved July $2^{\text {nd }}, 2013$ from URL: http://www.ejbss.com/recentaspx.

Usman, Y.D. (2016). Educational resources: An integral component for effective school administration in Nigeria. Research on Humanities and Social Sciences, 6(13), 59-68.

Uyanga, U.D., \& Emama, I.E. (2016). Education as an Instrument for Achieving Social Justice and Good Governance. Journal of Educational and Social Research. 6(2), 205-211.

Wolu, A.C. (2019). Availability and utilization of the school's resources. In N.P. Ololube (Ed.) Encyclopedia of Institutional Leadership, Policy and Management. A Handbook of Research in Honour of Professor Ozo-Mekuri Ndimele Volume III. Port-Harcourt, Pearl Publishers.

51 This work is licensed under a Creative Commons Attribution 4.0 International License. 